\title{
Ursolic Acid Enhances Doxorubicin Cytotoxicity on MCF-7 Cells Mediated by G2/M Arrest
}

\author{
Ibrahim Arifin ${ }^{1}$, Adam Hermawan ${ }^{2}$, Muthi' Ikawati ${ }^{2}$, Sari Haryanti ${ }^{3}$, \\ Anindyajati $^{4}$, Edy Meiyanto ${ }^{2 *}$ \\ ${ }^{1}$ Faculty of Pharmacy, Universitas Wahid Hasyim, Semarang, Indonesia \\ ${ }^{2}$ Department of Pharmaceutical Chemistry, Faculty of Pharmacy, Universitas Gadjah Mada \\ Jalan Sekip Utara, Yogyakarta 555281, Indonesia \\ ${ }^{3}$ Balai Besar Penelitian dan Pengembangan Tanaman Obat dan Obat Tradisional, Tawangmangu, Indonesia \\ ${ }^{4}$ Cancer Chemoprevention Research Center Faculty of Pharmacy, Universitas Gadjah Mada, JalanSekip Utara \\ 555281 (Phone. 02746492662 Fax. 543120) http://ccrc.farmasi.ugm.ac.id
}

\begin{abstract}
Ursolic acid has been widely known to possess biological activity against numerous tumor cell lines. Previous studies revealed its cytotoxicity on several cancer cells in vitro by either inducing apoptosis or cell cycle modulation. This study was conducted to investigate ursolic acid's cytotoxicity solely and in combination with a chemotherapeutic agent, doxorubicin, on MCF-7 breast cancer cells, followed by observation on its mechanism. Cytotoxicity of single and combinational treatment of ursolic acid and doxorubicin on MCF-7 breast cancer cells were conducted by using MTT assay. Single treatment was then evaluated by determining $\mathrm{IC}_{50}$ value, while combinational treatment was evaluated by analyzing cell viability and evaluating combination index $(\mathrm{Cl})$. To explore the mechanism underlying cytotoxic effect on respected cells, further analysis on cell cycle profile of single and combinational treatment was conducted by flow cytometry. Twenty four hours treatment of ursolic acid inhibited MCF-7 cells' growth with IC $_{50}$ value of $37 \mu \mathrm{M}$, while combinational treatment showed that several concentration combinations of ursolic acid and doxorubicin exhibited synergism of cytotoxic activity on MCF-7 cells, giving optimum $\mathrm{Cl}$ value of 0.54 Flow cytometric analysis showed that combinational treatment induced $\mathrm{G} 2 / \mathrm{M}$ arrest in MCF7 cells. These results show that ursolic acid is promising to be developed as either single chemopreventive agent, or as doxorubicin's co-chemotherapeutic agent in breast cancer treatment. Observation on the selectivity as part of safety aspect together with in silico, in vitro, and in vivo study on its molecular mechanism should be conducted.
\end{abstract}

Keywords: ursolic acid, doxorubicin,co-chemotherapeutic agent, breast cancer, cell cycle

\section{INTRODUCTION}

Ursolic acid, a pentacyclic triterpenoid found in plants, has been widely known to possess numerous biological activities, one of which is its activity against tumor cell lines. Previous researches observed that ursolic acid was able to inhibit SK-OV-3 and A2780 ovarian cancer cells growth by inducing apoptosis (Song et al., 2012) and HepG2 cells proliferation by inducing apoptosis and through cell cycle modulation (Tian et al., 2006). Another research reported that MCF-7 breast cancer cells proliferation was inhibited by ursolic acid through cell cycle modulation, indicating its possible potential as a medical component for breast neoplasm (Zhang et al., 2005).
Breast cancer has been widely known to be the cancer suffered most among women. To date, chemotherapy using cytotoxic chemotherapeutic agents are still the major choice of treatment in cancer, especially metastatic cancer (Drummond, 2007). Doxorubicin is one of cancer chemotherapeutic agent widely used in breast cancer treatment (Childs et al., 2002). Doxorubicin's cytotoxic effect occurs via p53 pathway. One of the major problems faced in doxorubicin therapy is the occurrence of resistance (Mechetner et al., 1998).

\footnotetext{
$\overline{\text { *Corresponding author e-mail: meiyan_e@ugm.ac.id }}$
} 
Cancer's resistance to doxorubicin occurs through various mechanisms, example drug inactivation, drug-pumping-out by efflux pumps on cell membrane, mutation of the target, and failure of apoptosis initiation (Davis et al., 2003; Notarbartolo et al., 2005). To overcome cancer's resistance towards existing chemotherapy agent, the application of cochemotherapeutic agent in cancer therapy could be done.

Previous research reported that ursolic acid inhibited MCF-7 cells growth by inducing apoptosis (Zhang et al., 2005). In this study, we observed ursolic acid's ability in increasing doxorubicin cytotoxicity on breast cancer cells, allowing the use of lower dose of the chemotherapeutic agent giving less toxicity on normal tissues. The study of its molecular mechanism is also necessary. This study aimed to examine the cytotoxicity of ursolic acid on MCF-7 breast cancer cells, continued with its effect in combination with doxorubicin.

\section{MATERIALS AND METHODS}

\section{Materials}

Ursolic acid (Sigma) was dissolved in Dimethyl Sulfoxide (DMSO) (Sigma). Both 5 $\mathrm{mg} / \mathrm{ml}$ doxorubicin (Ebewe) and ursolic acid solution were then diluted in DMEM cell culture medium before being applied. DMSO was used as the co-solvent in dissolving ursolic acid in DMEM culture medium.

For cytotoxicity assay, $10 \%$ sodium dodecyl sulphate (SDS) (Merck) dissolved in $0.01 \mathrm{~N} \mathrm{HCl}$ (Merck) as stopper reagent, phosphate buffer saline (PBS) $\mathrm{pH} \quad 7.4$ containing $\mathrm{KCl}$ (HPLC grade, Sigma), $\mathrm{NaCl}$ (HPLC grade, Sigma), $\mathrm{Na}_{2} \mathrm{HPO}_{4}$ (HPLC grade), and $\mathrm{KH}_{2} \mathrm{PO}_{4}$ (HPLC grade, Sigma) dissolved in aquadest as washing reagent, and 3-[4,5dimethyl thiazole-2-yl(-2,5diphenyltetrazoliumbromide)] (MTT) dissolved in PBS as MTT reagent were used.

For cell cycle analysis using flowcytometry, Phosphate Buffer Saline (PBS) pH 7.4, Propidium Iodide Solution $(50 \mu \mathrm{g} / \mathrm{ml}$ in PBS containing $1 \%$ Triton X-100) and RNAse DNAse-free $(20 \mu \mathrm{g} / \mathrm{ml})$ reagents were used.

\section{MCF-7 Cells Culture}

MCF-7 cells were obtained from the collection of Cancer Chemoprevention Research Center (CCRC), Universitas Gadjah Mada. The cell line was a gift from Prof.
Masashi Kawaichi, Nara Institute of Science and Technology (NAIST), Japan.

\section{Instruments}

Treated tissue culture dish $Q 10 \mathrm{~cm}$ (Iwaki), 96-well plate (Iwaki), 6-well plate (Iwaki), glassware, LAF hood (Labconco), $\mathrm{CO}_{2}$ incubator (Heraeus), inverted microscope (Zeiss MC80), cell counter, water bath, analytical balance (Sartorius), micropipette (Gilson), optical microscope, centrifuge (Sorvall), ELISA reader (SLT 240 ATC), yellow tip, blue tip, haemocytometer, conical tube (Nunc), shaker (MRK-RETAC), vortex, sterile eppendorf (Plasti Brand), digital camera (Canon, Japan), FACS Calibur (BD).

\section{Cytotoxicity and Combinational Assay}

MCF-7 cells were cultured in DMEM (Gibco) Culture Medium containing $10 \% \mathrm{v} / \mathrm{v}$ Fetal Bovine Serum (FBS) (Gibco) and 1\% Penicillin-Streptomycin (Gibco). TrypsinEDTA $0.25 \%$ (Gibco) was used in to deattached cells from TCD. The effect of ursolic acid alone and in combination with doxorubicin treatment on MCF-7 cells were measured based on MTT assay. MCF-7 cells were distributed to 96-well plate with the density of $5 \times 10^{3}$ cells/well and incubated in $37^{\circ} \mathrm{C}$ with $5 \% \mathrm{CO}_{2}$ for 24 hours. After 24 hours exposure of sample treatment, MTT reagent was applied, followed by 4 hours incubation. Stopper reagent was then applied. Plate was then kept with protection from light overnight, continued with absorbance determination ( $\lambda 595 \mathrm{~nm}$ ) using ELISA reader (Bio-Rad).

\section{Flow Cytometric Analysis}

MCF-7 cells were distributed in to 6-well plate with the density of $10^{6}$ cells/well. After 24 hours incubation, cells were treated with ursolic acid alone and in combination with doxorubicin. Following 24 hours treatment, cells were trypsinized and centrifuged at 2000 rpm for 3 minutes. Collected cell pellets were then washed twice with cold PBS. Cells were resuspended in propidium iodide solution and treated with RNAse DNAse-free for 10 minutes at $37^{\circ} \mathrm{C}$. Treated cells were then subjected to FACS flow cytometry.

\section{Data Analysis}

Single Cytotoxicity assay. Linear regression between ursolic acid concentration and $\%$ cell viability giving the equation $\mathrm{y}=\mathrm{Bx}$ 
+ A were used to calculate $\mathrm{IC}_{50}$ value, that is the concentration inhibiting $50 \%$ cell proliferation.

Combinational Cytotoxicity Assay. Cell viability resulted in combinational treatment between each treatment were analyzed statistically by one-way ANOVA by using SPSS 17.0. Combinational treatment was also evaluated by calculating

Combination Index (CI) value (Reynolds and Maurer, 2005), using the formula as follows.

$$
\mathrm{CI}=\frac{\mathrm{D}_{1}}{\mathrm{D}_{\mathrm{x} 1}}+\frac{\mathrm{D}_{2}}{\mathrm{D}_{\mathrm{x} 2}}
$$

$D_{1}$ and $D_{2}$ represent concentrations used in combinational treatment, while $\mathrm{D}_{\mathrm{x} 1}$ and $\mathrm{D}_{\mathrm{x} 2}$ are single treatment concentration giving the same response as $\mathrm{D}_{1}$ and $\mathrm{D}_{2}$, respectively. CI value acquired will allow the evaluation of ursolic acid's potency in combinational treatment with doxorubicin on MCF-7 cells. Interpretation was done based on the classification listed in Table I.

Flow Cytometry (Cell Cycle Profile).

Cell cycle distribution was acquired by using ModFit LT 3.0 program. Analysis was done on the proportion of S-phase, G1-phase, and G2/M-phase expressed as percentage.

Table I. Interpretation of $\mathrm{Cl}$ value representing potency of combinational application

\begin{tabular}{|c|c|c|c|}
\hline Cl value & Interpretation & Cl & Interpretation \\
\hline$<0.1$ & Very strongly synergist & $0.9-1.1$ & Closely additive \\
\hline $0.1-0.3$ & Strongly synergist & $1.1-1.45$ & Middle antagonist \\
\hline $0.3-0.7$ & Synergist & $1.45-3.3$ & Antagonist \\
\hline $0.7-0.9$ & Middle synergist & $>3.3$ & Strongly antagonist \\
\hline
\end{tabular}

\section{RESULTS AND DISCUSSION}

This study was conducted to explore ursolic acid's potency as doxorubicin's cochemotherapeutic agent against breast cancer, since MCF-7 breast cancer cells have been known to possess low sensitivity against doxorubicin (Zampieri et al., 2002).

\section{Ursolic Acid Inhibited MCF-7 Cells' Growth}

Single cytotoxicity assay was conducted to evaluate ursolic acid's cytotoxicity towards MCF-7 cells. Linear regression of ursolic acid concentration against \% cell viability (Fig. 1) gave value of $37 \mu \mathrm{M}$. Treatment of ursolic acid on MCF-7 cells showed cell growth inhibition in a concentration-dependent manner. Therefore, ursolic acid exhibited potent cytotoxic activity on MCF-7 cells according to Teng et al. (2005). Ursolic acid possesses higher cytotoxicity to MCF-7 cells compared to naringenin $\left(\mathrm{IC}_{50} 520 \mu \mathrm{M}\right)$, a flavonoid found in the genus citrus (Fitriasari et al., 2010). However, compared to solamargine $\left(\mathrm{IC}_{50} 2.1\right.$ $\mu \mathrm{M})$, a glycoalkaloid occurs in solanum species (Wei et al., 2011), ursolic acid possess relatively lower cytotoxicity on $\mathrm{MCF}-7$ cells. According to Meiyanto et al. (2012), despite of Citrus flavonoids' low cytotoxicity, they worked synergistically with doxorubicin to inhibit MCF-7 cells growth, revealing their potency as co-chemotherapeutic agents. We further observe ursolic acid's ability to enhance doxorubicin's cytotoxic effect on MCF-7 cells. Combinational assay was then conducted to observe whether ursolic acid would work synergistically with doxorubicin, a chemotherapeutic agent commonly used in breast cancer therapy, on $\mathrm{MCF}-7$ breast cancer cells. 


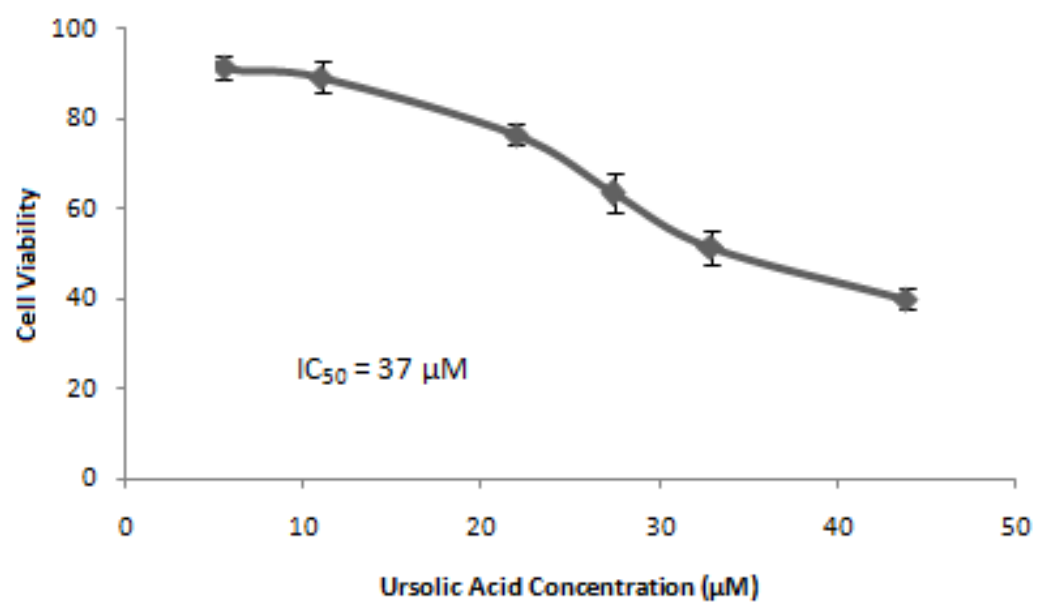

Figure I. Ursolic acid decreased MCF-7 cells' viability. Cell viability resulted from 24-hours treatment of ursolic acid on MCF-7 cells acquired by MTT assay. Five thousand cells per well were incubated and exposed with a series concentration of ursolic acid for 24 hours each. MTT reagent was then applied, followed by addition of stopper reagent and overnight incubation. Absorbance was determined at $\lambda 595 \mathrm{~nm}$ using ELISA reader. Ursolic acid inhibited cell growth in a dose-dependent manner, giving IC 50 value of $37 \mu \mathrm{M}$. Ursolic acid's cytotoxicity was represented as percentage of MCF-7 cells' viability as the mean \pm SE of three values.

\section{Ursolic Acid Increased Doxorubicin's Cytotoxicity on MCF-7 Cells}

Combinational treatment of doxorubicin and ursolic acid on MCF-7 cells was conducted to observe the ability of ursolic acid to increase doxorubicin's cytotoxicity on MCF-7 cells. We set the experimental design of combinational treatment based on single compound cytotoxicity, represented by $\mathrm{IC}_{50}$ values. Doxorubicin's $\mathrm{IC}_{50}$ value on MCF-7 cells was 350 nM (CCRC, unpublished data). Combinational treatment of ursolic acid and doxorubicin on MCF-7 cells resulted in higher cell growth inhibition compared to single treatment $(\mathrm{p}<0.05)$ (Table II, Fig. 2). Several concentration combinations showed synergism on MCF-7 cells, with CI values less than 0.9 (Table III). Cell morphology after treatment was also observed (Fig. 3). Treatment of ursolic acid and doxorubicin alone led to cells' morphological changes, (Fig. 3(B) and 3(C)). Combination of them caused more changes compared to single treated cells, and less viable cells (Fig. 3(D)), while control cells showed only slight changes in cells' morphology (Fig. 3(A)). Flow cytometric analysis was then conducted to observe cell cycle modulation of combination of ursolic acid and doxorubicin on MCF-7 cells. 


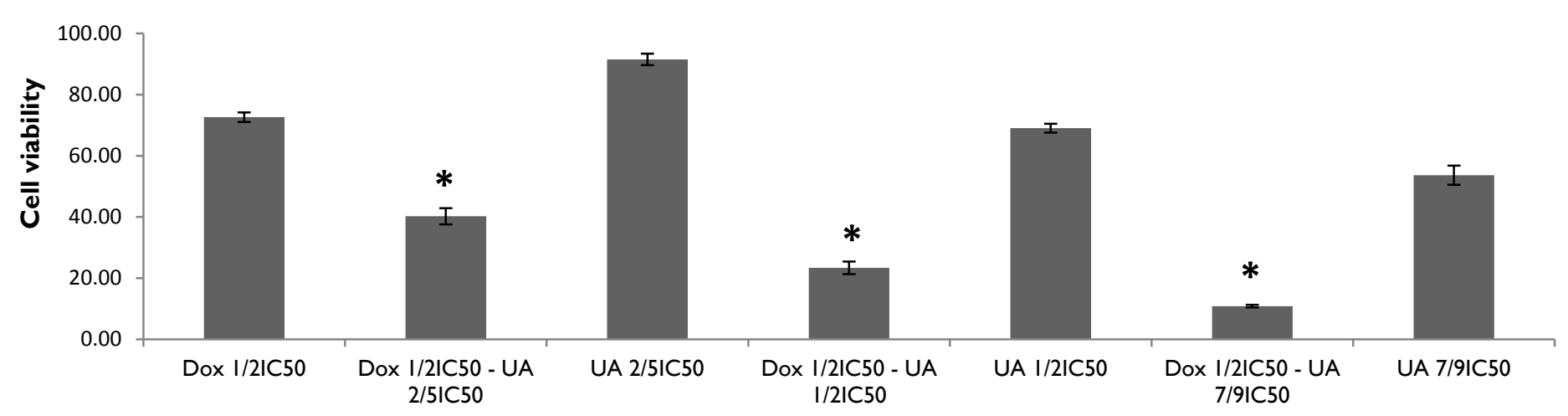

Treatment

Figure 2. Combination of ursolic acid and doxorubicin inhibited T47D cells growth. Twenty fourhours treatment of ursolic acid (UA) and doxorubicin (Dox) on MCF-7 cells examined by MTT assay. Five thousand cells per well were incubated for 24 hours and were exposed with various concentrations of ursolic acid and doxorubicin solely and in combination. MTT reagent was then applied, followed by addition of stopper reagent and overnight incubation. Absorbance was determined at $\lambda 595 \mathrm{~nm}$ using ELISA reader. One-way ANOVA statistical analysis was conducted to determine significant difference of cell viability yielded between treatments. Note $(*)$ shows significant difference of combinational treatment compared to single treatments (p 0.05). Combinational treatment of ursolic acid and doxorubicin yielded less cell viability compared to single treatment. Cytotoxicity was represented as percentage of MCF-7 cells' viability as the mean \pm SE of three values.

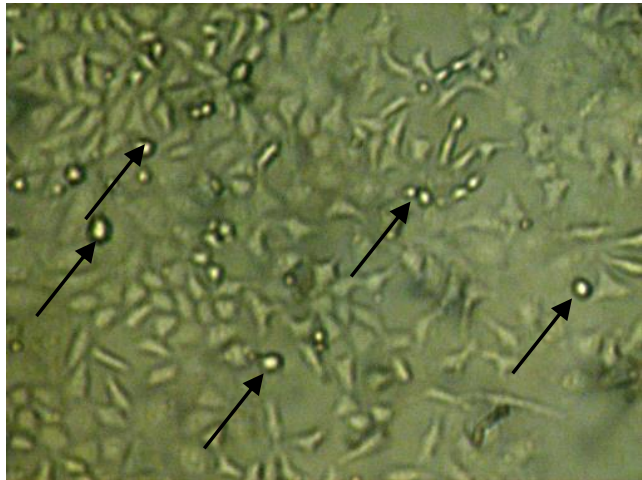

(A)

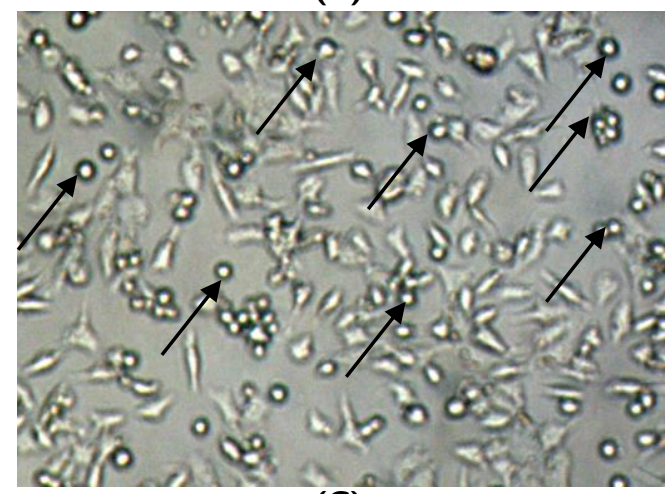

(C)

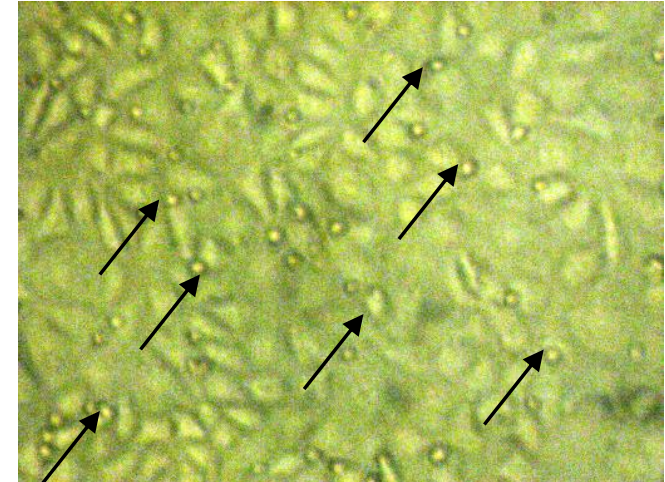

(B)

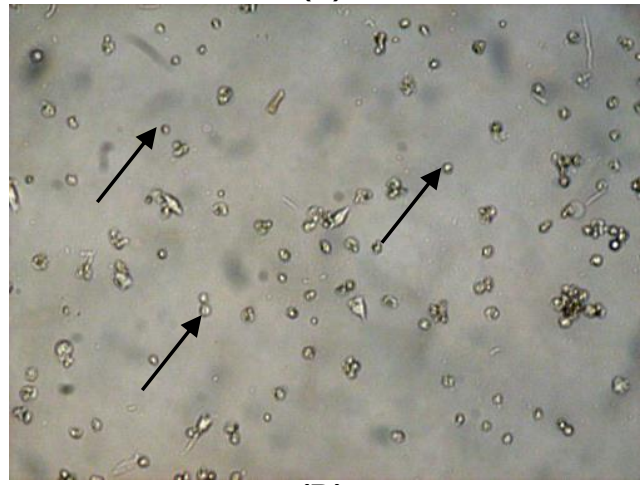

(D)

Figure 3. Combination of doxorubicin and ursolic acid showed synergism. Twenty four-hours treatment of ursolic acid and doxorubicin on MCF-7 cells. Cells were exposed with samples for 24 hours, followed by observation of 24-hours treatment of (A) vehicle only; (B) I/4 IC 50 doxorubicin; (C) 2/5 IC 50 ursolic acid; (D) I/4 IC 50 doxorubicin in combination with 2/5 IC 50 ursolic acid. Change in cell morphology is pointed with black arrows. Observation was done by using inverted microscope, 100x magnification. 
Table II. Effect of single and combinational treatment of ursolic acid and doxorubicin on MCF-7 cells viability.

\begin{tabular}{|c|c|c|c|c|c|}
\hline \multicolumn{6}{|c|}{ MCF-7 Cells Viability (\% viability \pm SE) } \\
\hline \multirow{2}{*}{$\begin{array}{c}\text { Ursolic acid } \\
\text { concentration }\left(\mathrm{IC}_{50}\right) \\
\mathrm{IC}_{50}=37 \mu \mathrm{M}\end{array}$} & \multicolumn{5}{|c|}{$\begin{array}{c}\text { Doxorubicin }\left(\mathrm{IC}_{50}\right) \\
\mathrm{I} \mathrm{C}_{50}=350 \mathrm{nM}\end{array}$} \\
\hline & 0 & $1 / 10$ & $1 / 4$ & $1 / 3$ & $1 / 2$ \\
\hline 0 & - & $124.20 \pm\left. 4.1\right|^{*}$ & $115.37 \pm 1.95^{*}$ & $93.54 \pm 1.56^{*}$ & $73.61 \pm 1.57 *$ \\
\hline $2 / 5$ & $91.50 \pm 1.87$ & $87.49 \pm 3.68 *$ & $61.00 \pm 2.68 *$ & $46.61 \pm 1.14^{*}$ & $40.23 \pm 2.63^{*}$ \\
\hline $\mathrm{I} / 2$ & $69.01 \pm 1.47$ & $63.45 \pm 2.34^{*}$ & $28.95 \pm 2.66 *$ & $28.78 \pm 1.6 \mathrm{I}^{*}$ & $23.39 \pm 2.06 *$ \\
\hline $7 / 9$ & $53.64 \pm 3.13^{*}$ & $40.31 \pm 2.44^{*}$ & $13.49 \pm 2.05^{*}$ & $13.49 \pm 1.02 *$ & $10.87 \pm 0.43 *$ \\
\hline
\end{tabular}

$*$ sign shows significant difference of cell viability resulted in combinational treatments compared to those yielded by both single treatments.

Table III. Combination Index of combinational treatment of ursolic acid and doxorubicin on MCF-7 cells.

\begin{tabular}{ccccc}
\hline \multicolumn{5}{c}{ Combination Index } \\
\hline \multirow{3}{*}{ Ursolic acid concentration $\left(\mathrm{IC}_{50}\right)$} & \multicolumn{5}{c}{ Doxorubicin $\left(\mathrm{I} \mathrm{C}_{50}\right)$} \\
\cline { 2 - 5 } & $\mathrm{I} / 10$ & $\mathrm{I} / 4$ & $\mathrm{I} / 3$ & $\mathrm{I} / 2$ \\
\hline $2 / 5$ & 2.65 & 3.26 & $\mathbf{0 . 6 9}$ & $\mathbf{0 . 5 9}$ \\
$1 / 2$ & 1.47 & 1.02 & $\mathbf{0 . 6 0}$ & $\mathbf{0 . 5 4}$ \\
$7 / 9$ & 1.17 & $\mathbf{0 . 6 0}$ & $\mathbf{0 . 6 5}$ & $\mathbf{0 . 6 3}$ \\
\hline
\end{tabular}

* Bold numbers shows combination resulting in $\mathrm{Cl}$ value below 0.9 , which are synergist.

\section{Ursolic Acid Solely and in Combination with Doxorubicin Altered Cell Cycle Profile of MCF-7 Cells}

In this research, treatment of ursolic acid alone led to $\mathrm{S}$ phase arrest, while doxorubicin induced accumulation in G2/M phase (Fig. 4). Combinational treatment of both compounds tends to increase cell population in G2/M phase (Fig. 4). G2/M arrest showed occurrence of disruption in cell growth process that may lead to apoptosis.

\section{Possible Underlying Mechanism and Proposed Future Studies}

Combinational treatment of ursolic acid and doxorubicin was conducted to explore ursolic acid's potency to be developed as cochemotherapeutic agent. The use of cochemotherapeutic agent having synergistic effect may allow the use of lower dosage of chemotherapeutic agent, resulting in the decrease of cytotoxicity on normal cells (Bastl et al., 2007). Combinational treatment of ursolic acid and doxorubicin on MCF-7 cells resulted in higher cell growth inhibition compared to single treatment exhibited synergism in several combinations of concentration. Cell growth inhibition may occur via either apoptosis induction or cell cycle modulation or both occurring consecutively. Zhang et al. (2005) and Kassi et al. (2009) reported that ursolic acid inhibited MCF-7 cells growth by downregulating $\mathrm{Bcl}-2$ that leads to apoptosis induction. Our study by flow cytometric analysis showed that ursolic acid alone led to $\mathrm{S}$ phase arrest, while in combinational treatment it tend to cause $\mathrm{G} 2 / \mathrm{M}$ arrest. Both $\mathrm{S}$ and $\mathrm{G} 2 / \mathrm{M}$ arrest showed disruption in cell growth process, which could be in either DNA synthesis or cytokinesis. That phenomenon may lead to apoptosis.

Another study revealed that ursolic acid-induced apoptosis was followed by a decrease in CDK4/cyclin D1 expression through suppression of FoxM1 expression (Wang et al., 2012). CDK4/cyclin D complex plays a role in G1 phase activation (Shah and Schwartz, 2006). Inhibition of G1 activation may lead to disruption of protein synthesis ( $\mathrm{S}$ phase), that may responsible for the $S$ phase arrest. A study revealing ursolic acid's effect to CDK2/cyclin, a complex that is responsible for the activation of $\mathrm{S}$ phase is suggested (Hsu et $a l .$, 2004). It has also been observed that ursolic acid increased p53 expression (Zhang et al., 2005). p53 protein will be expressed and activated due to DNA damage. The p53 will then induce the expression of cyclin dependent kinase inhibitors (CKIs), such as p21, p27, and p57 that play a role in inhibiting $\mathrm{CDK} /$ cyclin complex activity, resulting in the disruption of cell cycle (Foster, 2008). The effect of ursolic 
acid in combination with doxorubicin on proteins involved in $\mathrm{G} 2 / \mathrm{M}$ activation in $\mathrm{MCF}-7$ cells, such as MPF, are also proposed to be further studied, to understand the mechanism of ursolic acid's ability to increase doxorubicin's cytotoxicity on MCF-7 cells. One protein playing a role in cell growth and apoptosis is
$\mathrm{NF}-\kappa \mathrm{B}$, commonly found as heterodimer (Moynagh, 2005). Observation on the effect of ursolic acid treatment solely and in combination with doxorubicin to NF- $\kappa \mathrm{B}$ activation in $\mathrm{MCF}-$ 7 cells is also suggested. Besides, study on its selectivity of cytotoxicity is also needed.

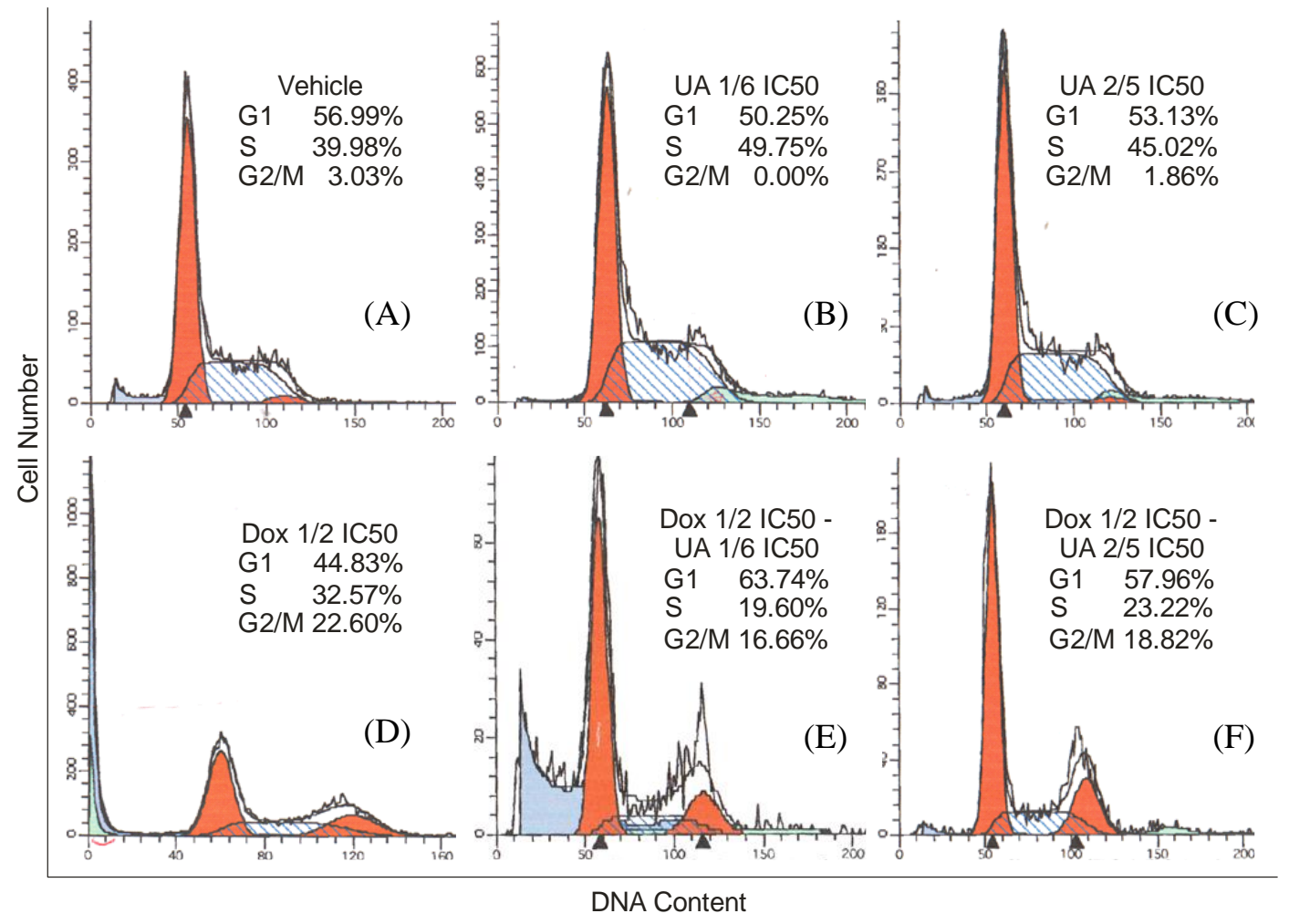

Figure 4. Ursolic acid solely and in combination with doxorubicin modulates cell cycle of MCF-7 cells. One million cells/well were incubated, followed by exprosure of samples for 24 hours. Cells were then trypsinized and collected. Following addition on $50 \mu \mathrm{g} / \mathrm{ml}$ propidium iodide solution and $20 \mu \mathrm{g} / \mathrm{ml}$ RNAse DNAse-free, cells were subjected to FACS flow cytometer. Data acquired were analyzed by using ModFit LT 3.0 program. Flow cytometric analysis of (A) vehicle-treated cells; 24-hours treatment of (B)I/IO IC 50 ursolic acid; (C) I/4 IC 50 ursolic acid; (D) I/2 IC 50 doxorubicin; (E) I/2 IC 50 doxorubicin in combination with I/IO IC 50 ursolic acid; (F) I/2 IC 50 doxorubicin in combination with I/4 IC 50 ursolic acid on MCF-7 cells.

According to the data above, we conclude that ursolic acid is promising to be developed as single chemopreventive agent, and also as doxorubicin's co-chemotherapeutic agent in breast cancer treatment. Observation on its selectivity as part of safety aspect is also needed. Further in silico, in vitro, and in vivo study on its molecular mechanism also should be conducted.

\section{ACKNOWLEDGEMENT}

We would like to express our gratitude to International Collaboration Research Grant 2012, Ministry of Education Indonesia, who funded and supported this research.

\section{REFERENCES}

Bastl, A., Kaseirov, H., Den Hartog, G.J.M., Haenen, G.R.M.M., and Van Der Vijgh, 
W.J.F., 2007, Protectors Against Doxorubicin-Induced Cardiotoxicity: Flavonoids, Cell Biol Toxicol, 23, 39-47.

Childs, A.C., Phaneuf, S.L., Dirks, A.J., Phillips, T. and Leeuwenburgh, 2002, Doxorubicin Treatment In Vivo Causes Cytochrome c Release and Cardiomyocyte Apoptosis, as well as Increased Mitochondrial Efficiency, Superoxide Dismutase Activity, and Bcl-2:Bax Ratio, Cancer Research, 62, 4592-4598.

Davis, J.M., Navolonic, P.M., Weinstein, C.R., Steelman, L.S., Hu, Konovlepa, M., Blagosklonny, M.V. and McCubrey, J.A., 2003, Raf-l and Bcl-2 Induce Distinct dan Commn Pathway That Contribute to Cancer Drug Resistance, Clin. Cancer Res., 9, I|6III 70.

Drummond, C., 2007, The Mechanism of Antitumour Activity of the DNA Binding Agent SN 28049, Thesis, University of Auckland, New Zealand.

Fitriasari, A., Susidarti, R.A. and Meiyanto, E., 2010, Peningkatan Efek Sitotoksik Doxorubicin oleh Naringenin Melalui Pemacuan Apoptosis Sel Kanker Payudara MCF-7, Jurnal Bahan Alam Indonesia, 7(3), I65-I70.

Foster, I., 2008, Cancer: A Cell Cycle Defect, Radiography, I4, I44-I49.

Hsu, Y. L., Kuo, P.K., Lin, C.C., 2004, Proliferative inhibition, cell-cycle dysregulation, and induction of apoptosis by ursolic acid in human non-small cell lung cancer A549 cells, Life Sciences, 75(19), 2303-23 I6.

Kassi, E., Sourlingas, T.G., Spiliotaki, M., Papoutsi, Z., Pratsinis, H., Aligiannis, N. and Moutsatsou, P., 2009, Ursolic Acid Triggers Apoptosis and $\mathrm{Bcl}-2$ Downregulation in MCF-7 Breast Cancer Cells, Cancer Invest., 27(7), 723-733.

Mechetner, E., Kyshtoobayeva A., Zonis S., Kim H., Stroup R., Garcia R., Parker R.J. and Fruehauf, J.P., 1998, Levels of Multidrug Resistance (MDRI) PGlycoprotein Expression by Human Breast Cancer Correlate with in vitro Resistance to Taxol and Doxorubicin, Clin. Cancer Res., 4, 389-398.
Meiyanto, E., Hermawan, A. and Anindyajati, 2012, Natural Products for CancerTargeted Therapy: Citrus Flavonoids as Potent Chemopreventive Agents, Asian Pac. J. Cancer Prev., I 3, 427-436.

Moynagh, P.N., 2005, The NF-kB Pathway, J. Cell Sci., I I 8, 4589-4592.

Notarbartolo, M., Poma, P., Perri, D., Dusonchet, L., Cervello, M., and Alessandro, N., 2005, Antitumor Effects of Curcumin, Alone or in Combination with Cisplatin or Doxorubicin, on Human Hepatic Cancer Cells: Analysis of Their Possible Relationship to Changes in NF-kB Activation Levels and in IAP Gene Expression, Cancer Letters, 224, 53-65.

Reynolds, C.P. and Maurer B.J., 2005, Evaluating Response to Antineoplastic Drug Combinations in Tissue Culture Models, Methods in Molecular Medicine, I I 0, I73-I83.

Shah, M.A. and Schwart, G.K., 2006, Cyclin Dependent Kinases as Targets for Cancer Therapy, Update on Cancer Therapeutics, I, 31 I-332.

Song, Y.H., Jeong, S.J., Kwon, H.Y., Kim, B., Kim, S.H. and Yoo, D.Y, 20I2, Ursolic Acid from Oldenlandia diffusa Induces Apoptosis via Activation of Caspases and Phosphorylation of Glycogen Synthase Kinase 3 Beta in SK-OV-3 Ovarian Cancer Cells, Biol. Pharm. Bull., 35(7), 1022-1028.

Teng, W.Y., Huang, Y.L., Shen, C.C., Huang, R.L., Chung, R.S. and Chen, C.C., 2005, Cytotoxic Acridone Alkaloids from the Stem Bark of Citrus Maxima, J. of the Chinese Chem. Soc., 52, I253-1255.

Tian , Z., Lin, G., Zheng, R.X., Huang, F., Yang, M.S., and Xiao, P.G., 2006, Antihepatoma Activity and Mechanism of Ursolic Acid and Its Derivatives Isolated from Aralia decaisneana, World J. Gastroenterol, I 2(6), 874-879.

Wang, J.S., Ren, T.N., and Xi, T., 20I2, Ursolic Acid Induces Apoptosis by Suppressing the Expression of FoxMl in MCF-7 Human Breast Cancer Cells, Med. Oncol., 29(I), I0-I5.

Wei, G., Wang, J., and Du, Y., 20II, Total Synthesis of Solamargine, Bioorganic 
and Medicinal Chem. Letters, 21, 29302933.

Zampieri, L., Bianchi, P., Ruff, P., and Arbuthnot, P., 2002, Differential Modulation by Estradiol of P-glycoprotein Drug Resistance Protein Expression in Cultured MCF7 and T47D Breast
Cancer Cells, Anticancer Res., 22, 2253-2259.

Zhang , W., Li, Y., Zhang, G., Lu, J., and Ou, H., 2005, Experimental Study on MCF-7 Cell Apoptosis Induced by Ursolic Acid, Zhong Yao Cai, 28(4), 297-30I. 